\title{
James Beattie and the Great Outdoors: Common Sense Philosophy and the Pious Imagination
}

On writing to Boswell in 1773, James Beattie's annus mirabilis, Samuel Johnson declared: 'Beattie is so caressed, and invited, and treated, and liked, and flattered, by the great, that I can see nothing of him'. ${ }^{1}$ Beattie's almost exact contemporary William Cowper claims to 'see' Beattie, but only in bewilderingly hyperbolic terms: 'his own character appears in every page, and, which is rare, we see not only the writer but the man. And that man so gentle, so well-temper'd, that it is necessary to love him if one has the least sense of what is lovely'. ${ }^{2}$ In 1773 James Beattie's popular success was granted its permanent apotheosis by Joshua Reynolds in his allegorical painting 'The Triumph of Truth', which is now housed in Marischal College Aberdeen. Reynolds' Beattie smiles modestly, and is dramatically lit against a stormy background. He grips a copy of his own book of philosophy, a sure defence against the whirling chaos around him. Meanwhile, his enemies Voltaire and Hume are confounded and thrust into the darkness.

Beattie's ascendancy was brief, although Reynolds' extravagant image is a reminder that it had been a major cultural phenomenon. The debt owed by the romantics to Beattie is an obvious one, acknowledged by Wordsworth in particular. As late as 1820 , John Clare's publisher insisted that 'the peasant poet' christen his latest volume The Village Minstrel. John Lucas regards this as a deliberate attempt to cash in on the enduring popularity of Beattie's poem - 'that sentimental tale of the inspired bard'. Very recently, Everard King has noted Beattie's proto-Coleridgian understanding of the difference between fancy and imagination, showing how The Prelude and The Excursion expand latent possibilities in the first and second parts of The Minstrel respectively. T. J. Diffey refers to the influence of Beattie's aesthetic theory on developing 'romantic' ideology. Robert Gittings connects The Minstrel with the The Eve of St. Agnes and Marilyn Gaull identifies Beattie's fingerprints on Shelley's Alastor and Byron's Childe Harold's Pilgrimage. ${ }^{3}$ These and other connections are so various and so plausible that the case for Beattie's importance is in danger of being prematurely closed once too 
easily established. Insufficient attention has been paid to the nature as opposed to the mere extent of The Minstrel's reverberative capacity. King at least hints at a more interesting trail of influence: 'Not only did early readers interpret the poem as a special kind of refutation of sceptical philosophy but also they may have read the dichotomy in the poem between reason gone mad and the restorative power of nature as an indication of the dawn of a new age of enlightenment and culture'. ${ }^{4}$ Even when uncapitalised, 'the age of enlightenment' is, surely, an unfortunate phrase. 'Reason gone mad' is a better pointer however, illuminating one of Beattie's central concerns and identifying a continuum of oppositional thinking which links Beattie decisively with evolving romantic sensibility. For aside (but scarcely apart) from all the conscious and unconscious borrowings, the abstractions, the circumlocutions, and the metaphorical topographics, there is a profound identity of concern which repays study. Beattie and Wordsworth share a need for a philosophy of the great outdoors, a philosophy that imposes itself gradually on the senses and claims a holistic rather than a merely intellectual authority, a philosophy that somehow accommodates empirical positivism alongside abstraction and introspection. Beattie demands a philosophy that offers practical and enduring faith, not just persuasive formulae; his natural religion accordingly claims to be more provisional and yet more solid than academic philosophy.

Dorothy Wordsworth writing to Jane Pollard on 10 July 1793 describes her brother as a "'strange and wayward wight"' - in other words, as Beattie's 'Minstrel' Edwin. '[I]ndeed the whole character of Edwin resembles ... William' she continues in the same letter. ${ }^{5}$ Describing a recent walk in the vicinity of Lyme Regis, 20 October 1795, this wayward William/Edwin quotes from The Minstrel in order to focus his emotions in response to the majestic sound of the ocean (Wordsworth Letters, p. 154). His debt to Beattie is underwritten by a peculiar fascination with the latter's central imaginative concerns - not only with the writer, but with Beattie the man.

For Beattie as for Wordsworth Nature in all its mysterious plenitude is the source, or at least arena, of spiritual salvation. The Minstrel declares that appreciation of the natural world is a prerequisite for religious reclamation:

Oh how canst thou renounce the boundless store Of charms which Nature to her votary yields! The warbling woodland, the resounding shore, The pomp of groves, and garniture of fields; All that the genial ray of morning gilds, And all that echoes to the song of even, All that the mountain's sheltering bosom shields, 
And all the dread magnificence of Heaven, Oh, how canst thou renounce, and hope to be forgiven!

$(\text { Book I, IX, })^{6}$

Unlike Wordsworth at Racedown Lodge or at Grasmere, Beattie had the benefit both of 'Nature's charms' and stimulating intellectual companionship close at hand. Eighteenth-century Aberdeen was a powerful contributor to the European Enlightenment. In the common rooms and taverns in and around Marischal and King's Colleges, the fields of literary theory, philosophy, linguistics, and sociology were developed and interlinked - for example at meetings of the Aberdeen 'Wise Club', an informal body dedicated to interdisciplinary inquiry and mutual congratulation. In 1764 the most serious philosopher within the group, Thomas Reid, published An Inquiry into the Human Mind, on the Principles of Common Sense - a neo-empiricist attack on Hume and Berkeley. It was left to Beattie to recast much of Reid's argument within a vastly more popular work, his Essay on the Nature and Immutability of Truth, in Opposition to Sophistry and Scepticism (1770). Scepticism, argued Beattie, is all about demonstrating the unbelievable; exhibiting formal proofs without inspiring belief: 'I have known many who could not answer Berkeley's arguments', he affirmed, 'I never knew one who believed his doctrine.' 7 Philosophy should inspire more than mere intellectual assent to certain propositions; it should be about life, life should be about faith and faith should be about feeling: 'I ought to be convinced only when I feel conviction; when I feel no conviction, I ought not to be convinced' (Beattie, Essay on Truth, p. 286). You cannot (in other words), put down your books, leave your study and (like Hume) live a fairly normal life. Hume and Berkeley had a responsibility either fully to inhabit their own philosophy or to abandon it. Every time either of them walked around a hole in the road, or stepped aside to avoid a fast-moving vehicle, they betrayed and discredited their life's work.

The Essay on Truth took four years (1765-9) to write. In a letter to Thomas Gray of 1 May 1770 Beattie bemoans the fact that he had been forced to start reading contemporary philosophers having been awarded the chair of Moral Philosophy at Marischal: 'I had little relish for them from the first, and as I began to understand them better, I hated and despised them the more'. 8 Beattie saw his role as moral philosopher as a reassurer and reinforcer of intuitive impulses, undermining metaphysics from within, with Common Sense as his multi-purpose tool of sabotage: 'it may be urged as an objection ... that, if we grant common sense to be the ultimate judge in all disputes, a great part of ancient and modern philosophy becomes useless. I admit the objection with all my heart, in its full force and with 
all its consequences' (Beattie, Essay on Truth, p. 143). In a letter to William Forbes, 31 January 1766, Beattie remarks 'I have of late been much engaged in metaphysics; at least I have been labouring with all my might to overturn that visionary scheme. ${ }^{9}$ There is obvious slippage as to whether Beattie is engaged in or engaged with metaphysics. It is notable that Beattie casually implies that all systems of metaphysics somehow form one evil scheme. And the word 'visionary' presents special pivotal problems which require detailed attention.

Beattie detests controversy, formal logic and above all, linguistic philosophy, philosophy which plays on the ambiguity of words so as to deconstruct the conceptual universe. Reid had claimed that modern sceptics have created their critique of causality by abusing the plain meaning of words. Beattie seizes on the hint: 'A verbal disputant! What claim has he to do with the laws of nature, with the observation of facts, with life and manners! Let him not intrude upon the company of men of science; but repose with his brethen Aquinus and Suarez, in the corner of some Gothic cloister, dark as his understanding, and cold as his heart' (Beattie, Essay on Truth, p. 2). The 'cloister' is of course a familar abusive metonym for scholastic philosophy, but Beattie invests the term with renewed oppositional vigour. Bad philosophy always emanates from enclosed places. Good philosophy is contained only by the vault of heaven. Throughout the Essay on Truth there is an indoor/outdoor dichotomy that craves the bolder expression permissable in The Minstrel which was being written concurrently. While Beattie was sweating over his Hume, Edwin was roaming the countryside. Forty years later, The Prelude would contrast the unsatisfying educative atmosphere of formal college life with William's renewed receptive capacity once mountains and lakes are again supplied. For Beattie the minstrel and the metaphysician are both described as 'visionary', but the clear vision of the receptive, passive votary is opposed to the clouded vision of the conceited, blinkered theorist. Beattie writes in starkly personal terms about this contrast in a letter to Captain Mercer, 26 November 1769, having recently completed his pious chore of refuting Hume: 'I am like a man who has escaped from the mines, and is now drinking in the fresh air and light, on top of some of the mountains of Dalecarlia' (Letters, I, p. 75). Beattie's primary quarrel with.Hume is not, apparently, epistemological but medical.

Beattie's own hypochondria fuels a correspondence that is steeped in physical suffering. It is true that much of his mental anxiety was grounded in real tragedy (his wife suffered from insanity and both his sons were to die prematurely) but it is, above all, fatalistic diagnoses of his own failing health that dominate his private letters over the course of decades. The continuity between Beattie's physical, psychological and intellectual trials 
is remarkable. Contextualising Edwin's adventures in The Minstrel, the narrator explains that modern philosophy is fast becoming an epidemic of mental and physical debilitation. Heaven intended the imagination to soar - philosophy makes it creep:

Thus Heaven enlarged his soul in riper years.

For Nature gave him strength and fire, to soar

On Fancy's wings above this vale of tears;

Where dark cold-hearted sceptics, creeping, pore

Through microscope of metaphysic lore:

And much they grope for Truth, but never hit.

For why? Their powers, inadequate before,

This art preposterous renders more unfit;

Yet deem they darkness light, and their vain blunders wit.

(Book I, LI)

Scepticism is a form of progressive myopia - destructive 'poring' enfeebles to the point where healthy and expansive 'vision' becomes impossible. At the same time, the less people see the more they 'deem' they know. Elements of Moral Science consolidates this paradigm: 'Every science, and moral science especially, ought to refresh the mind with the knowledge of truth, and give strength to the human faculties, by establishing rules for the regulation of human conduct, both in common life, and in the pursuits of literature. But this speculative metaphysick can answer no end, that is not either bad or frivolous'. ${ }^{10}$

The human intellect requires regular airing. Philosophy should open a window of refreshing reality in order to regenerate the mind. Hume and Berkeley, by shutting up all the doors and windows, denying the objective referential reality of Created Nature, cause fetid air to circulate and poison the intellectual constitution. Composing The Minstrel was Beattie's refreshment, and he describes turning from Hume to Edwin as though he were coming up for air. The Ancients were (as usual) wiser and more holistic than the Moderns in this respect. Beattie remarks approvingly that in Athens 'men were not cooped up in palaces and coaches; they were almost constantly in the open air; and on foot'.11

Despite its sometimes tedious reductionist rhetoric, the 'Common Sense' school of philosophy (Reid, Beattie, Thomas Campbell and James Oswald) was not without intellectual credentials; its genealogy runs through Shaftesbury and Hutcheson, with a sideways branch leading to Butler. Joseph Priestley was surely correct, however, when he warned that the popularity of 'Common Sense' threatened ultimately the end of philosophy as a discrete discipline. Priestley calculated that at the present rate in ten 
years more $[\ldots]$ the whole business of thinking will be in a manner over, and we shall have nothing to do but to see and believe.' ${ }^{12}$ Kant complained that Beattie's Essay was nothing better than an appeal to the verdict of the multitude. However Beattie characteristically saw nothing wrong with qualified majority voting as a test of truth. Philosophers have a responsibility to respect the bulk of humanity and to treat their insights seriously since among 'the people . . nature appears with the least disguise' (Essay on Truth, pp. 466-7). If there is something agreeably democratic about Beattie's appeal to the 'common sense' axioms of ordinary men and women, there is also something potentially (and effectively) very reactionary about it. If common sense is virtually ubiquitous then what is virtually ubiquitous is common sense, and established systems of government and political economy are best left alone. Beattie's late work, The Elements of Moral Science (1790-3), is urgently anti-revolutionary: to imagine that one can build a nation on the bold hypotheses of philosophes is a disturbing (if unforeseen) extension of the primary intellectual sin of Hume - that 'indoor' visionary. Common Sense spoken with an Aberdonian accent belongs therefore to Burke and not to Paine.

The single most romantic or radical aspect of The Minstrel is its celebration of potential rather than kinetic energy - its suggestion that 'experience' is just corruption by another name. Like Gray, Beattie prefers promise to performance. He abandoned a third book of The Minstrel in which Edwin leads his countrymen in battle - in other words, where he actually does something. Edwin's titular calling is an ontological definition - he will remain a minstrel whether or not he produces anything; poems might be symptoms of his identity, but they could never establish or prove it. The bard or minstrel is the telos rather than the originator of the creative process, and the close concentration on formative poetic growth has obvious successors and interesting predecessors. One of Beattie's earliest encouragers was Thomas Blackwell, the Aberdonian professor whose Inquiry into the Life and Writings of Homer (1735) is a speculative survey of the conditions - personal, historical, social and geographical - required to produce an epic poet. Blackwell's bard is a loner, materially poor and prone to introspection. Imaginative endeavour comes easier to those whose isolation precludes distractions: 'When alone, we are obliged to furnish out our own Entertainment; we must recollect ourselves and look within, if there be anything that merits our Attention.' ${ }^{13}$ The Minstrel similarly celebrates solitude as the true basis for creative sublimity. Anyone seeking glory without introspection is deluded by a false aesthetic: 'O Solitude, the man who thee forgoes, / When lucre lures him, or ambition stings, / Shall never know the source whence real grandeur springs' (Book II, X). 
Beattie's 'proto-romantic' praise of solitude was already something of a literary commonplace. Throughout the 1750 s and 60 s words such as wander, meander and stray (all formerly associated to varying degrees with sinful 'error') had been re-energised as positive terms of literary value. William Duffs Essay on Original Genius (1767) proclaims Gray, Young, Ogilvie and Akenside as the great 'originals' of his day. The measure of immortal worth of these poets is directly bound up with their lack of contemporary engagement: 'True Genius, removed from the din and tumult of business and care, shoots up to the noblest height; it spreads forth all its luxuriance in the peaceful vale of rural tranquillity'. ${ }^{14}$ Beattie defends these same poets in a poem attacking proposals to erect a monument to Charles Churchill in Westminster Abbey:

Is this the land, where Gray's unlabour'd art

Soothes, melts, alarms, and ravishes the heart

While the lone wanderer's sweet complainings flow

In simple majesty of manly woe ... 15

The fact that Churchill's egocentric digressions will one day be established as part of the same proto-romantic moment that encompasses Beattie is, of course, irrelevant. The Abbey's sepulchral vaults must transcend the 'here and now' of polemical discourse or else Poets' Corner becomes Poets' cul de sac.

Blackwell, Beattie and Gray together produced influential versions of the itinerant bard, and in doing so explore many of the same issues suggested by Rousseau's famous competition essay question, the question as to whether civilisation has diminished rather than enhanced the creative capacity of humanity? ${ }^{16}$ Blackwell's Homer taunts degenerate moderns with their sophisticated diversions partly on the basis that solitude was easier to come by in antiquity: 'The way to think little, is to hurry from one Amusement to another, that we may fly from ourselves.' (Blackwell, p. 121). The integrity of a poem becomes a psychological, rather than a formal or technical qualification. Blackwell's bard wanders both externally and internally, achieving self-knowledge continuously with bodily exercise. Homer (anticipating Edward Young) apparently knew that sublimity was obtained by marvelling at the ambitious yearnings of selfhood. As Beattie declares: 'It is in the works of nature, particularly in the constitution of the human soul, that we discern the first and conspicuous traces of the Almighty' (Beattie, Essay on Truth, pp. 14-15).

In his 'Essay on Poetry and Music' (1776), Beattie takes this autoluxuriance a stage further: 'Many things in art and nature exceed expectation; but nothing sensible transcends, or equals, the capacity of 
thought: - a striking evidence of the dignity of the human soul' (Beattie, Essays, p. 49). Reid makes the same point when refuting Hume: 'When I look within and consider the mind itself, which makes me capable of all these prospects and enjoyments; if it is indeed what the Treatise of Human Nature makes it, I find I have been only in an enchanted castle, imposed upon by spectres and apparitions'. ${ }^{17}$ Beattie expanded on this metaphor in The Castle of Scepticism, an unpublished prose satire on Hume's philosophy reminiscent of Thomson's Castle of Indolence and Fielding's Journey from this World to the Next. ${ }^{18}$ Written in 1767, it depicts Hume as governor of a gloomy, enchanted castle who dupes his too-willing prisoners into thinking that the pleasant countryside outside is a land of prejudice and error. Governor Hume's strange intellectual fancy differs from creative poetic fancy in that his sceptical philosophy appeals first and foremost to the herd mentality of fashionable triflers, with their incessant desire for novelty and paradox. Humean fancy is smugly self-reinforcing but also self-limiting. His prisoners are too socially insecure to permit common sense ever to announce that their emperor has no clothes. In the words (already quoted) of The Minstrel, they 'deem ... darkness light'. The reversal of values in Hume's castle is anything but liberating as it is enforced by arrogance and by slavish fashion.

Beattie's Hume has been blessed with good eyesight, but is voluntarily blind. Although those 'visionary' bards Homer and Milton cannot actually see the landscapes they describe, their vocational regime cultivates and sustains their inner life. Inwardness is thus associated with extremes of inspiration and self-delusion. Significantly, the inward is the terrain of the great Anglican theologian, Joseph Butler. Beattie's Evidences of the Christian Religion (1786) cites Butler repeatedly and admiringly. ${ }^{19}$ In the Essay on Truth (p. 120), Beattie refers his readers to Butler's Analogy of Religion as the perfect refutation of Hume's 'flimsy essay', unaware that Hume was one of Butler's greatest admirers. Hume had considered sending Butler an early draft of the Treatise, following Butler's critique of empirically derived theories of causality.

Butler, Berkeley and Hume together demonstrate that fideism and atheism are two sides of the same coin, albeit it is a coin the majority of common-sense Christians would rather not see tossed. Beattie does not see the need for a leap of faith - a gentle stroll should suffice; Christian truths may be sublime, but do not require a sublime imagination to absorb them, just a sane and a humble spirit. The evidence for Christianity may be 'too sublime' for Hume but 'to the humble and tender-hearted, is altogether overwhelming, irresistible, and divine' (Beattie, Essay on Truth, p. 112). Beattie comes to minister not to the sick but to those easily shamed out 
of their hypochondria. He intends not to cure the sceptic but to reassure those frightened by the intellectual credentials of scepticism. His appeal is to aesthetic solidarity: sublimity is something that is either understood or it is not. In a similar vein, the dying Lord Kames explained to Boswell the real cause of Hume's infidelity (4 December 1782): 'David's atheism was owing to his want of sensibility. He did not perceive the benevolence of the Deity in all his works. He had not taste, and therefore did not relish Shakespeare'. ${ }^{20}$ Beattie would have applauded this diagnosis. Voltaire, another inhabitant of The Castle of Scepticism, augments and reinforces his other impieties by pouring scorn on Shakespeare and Milton. It is no accident that the aesthetic school of Christian apologetics develops concurrently with the accelerating perfection of bardolatory in literary history. In a letter to Robert Arbuthnot (26 November 1785), Beattie rhapsodised over Elizabeth Montagu's response to Voltaire's attack on Shakespeare (Letters, II, p. 137). Shakespeare weighs in alongside the constructively empirical philosophers in Beattie's roll of honour: 'Would you know what genius is, and where it may be found? Go to Shakespeare, to Bacon, to Montesquieu, to Rousseau; and when you have studied them, return, if you can, to HUME, and HOBBES, and MALEBRANCHE, and LIEBNITZ, and SPINOSA' (Beattie, Essay on Truth, p. 453).

From Shakespeare we can construct a true representation of humanity, whereas Hume's Treatise 'would convey no information to the planetary stranger' (Beattie, Essay on Truth, p. 458). Even extra-terrestrials prefer Shakespeare to phenomenology. In a letter to Charles Boyd (16 November 1766), Beattie asks 'Do not you think there is a sort of antipathy between philosophical and poetical genius? .. . Poetry exhibits general qualities of a species, philosophy the particular qualities of individuals' (Letters, I, p. 36). Poetry is supposedly truer than philosophy because it has to acknowledge ill-defined, generalised sentiment. Lack of precision is therefore the poet's advantage and opportunity. The Minstrel has harsh words for those who delimit the scope of experience with their close metaphysical formulae:

Hence! ye who snare and stupefy the mind, Sophists, of beauty, virtue, joy, the bane!

Greedy and fell, though impotent and blind, Who spread your filthy nets in Truth's fair fane.

And ever ply your venom'd fangs amain!

Hence to dark Error's den, whose rankling slime

First gave you form! hence! Lest the Muse should deign,

(Though loath on any theme so mean to waste a rhyme) With vengeance to pursue your sacrilegious crime.

(Book I, XLI) 
Unlike Campbell and Reid, Beattie did not know (and like) Hume, and was disinclined to treat him with any scholarly deference. He refused to assimilate the widespread accounts of Hume's practical common sense and benevolence. Beattie, unashamedly angry about the Essay on Miracles, is less philosophically cogent and more readable than almost any other contributor to the debate. Having been (as he saw it) personally injured by Hume, Beattie designed the Essay on Truth as, in part, a work of hard psycho- and physiotherapy. Reading contemporary metaphysics is for Beattie at best a disagreeable inoculation - a controlled form of exposure that will hopefully help him build up and transmit a resistance to a spreading virus of conceited scepticism. Only by berating the arrogance and corruption of the philosophic intellect can Beattie properly juxtapose and define his own positive norms of value, norms which were being poetically formalised simultaneously in The Minstrel.

Within a hectic polemical context, key Wordsworthian themes emergerecollection, renovation, and restoration - preoccupations that make The Minstrel one of the four or five most influential poems of its time. As a vindicator of naive presupposition as a basis for philosophical truth, Beattie is a decisive celebrant of childhood. Youthful innocence is an essential emblem within his own system of moral oppositions. At the opposite pole from the young impressionable Edwin, Beattie imagines something like the famous Alan Ramsay portrait of Hume, over-fed, over-dressed and over-read.

Ultimately, I would appear to be arguing that early romanticism developed in the way it did because James Beattie's inability to cope with Humean epistemology forced him to go and take long walks in the country. Simplistic as this may sound, it nonetheless seems to me to be one valid way of considering the issue. Beattie's insistence that there is a limit to the quality of wisdom that can be acquired sitting at a desk becomes, before very long, a serious and an influential way of thinking. When threatened by modern philosophy, head for the hills, where the insane truths of the metaphysician evaporate under the sane regime of the physician. Considered as a whole, Beattie's career dramatises a lifelong wrestling with different concepts of truth. Reid and Beattie concluded that intuitive truth is preferable to deductive truth since all deduction is derived from the juxtaposition of self-evident axioms. True wisdom consists of that 'negative capability' of withholding the epistemological scalpel and resting in a state of faith: 'Truth, like Virtue, to be loved, needs only to be seen' (Beattie, Essay on Truth, p. 19). Once people start treating created nature as mere sensedata, with no necessary objective existence, they are on a slippery slope to oblivion. Beattie, Campbell and Reid intend to chase this fatal error back 
to Descartes and re-institute the reality of experiential knowledge assumed by Bacon. The proto-romantic elements of Beattie's poetic credo require this philosophical victory: without sane empiricism one cannot have wise passivity. No one can stand and feel the truth of Nature while staging interminable hermeneutic contests between the relative merits of primary and secondary ideas.

Sane empiricism is the working method of childish education; childhood is the place where things are not yet mediated and compromised by words. Over-exposure to the culture of adult humanity causes us to forget and discredit the numinous power of the physical world. Beattie exclaims: 'Shall I suffer the ambiguities of artificial language to prevail against the clear, the intelligible, the irresistible voice of nature?' (Beattie, Essay on Truth, p. 71). By artificial language, Beattie means of course sophistical language - language that is artfully contrived. However, the attempts to delineate abstracted unmediated peaks of experience in The Minstrel could imply that he secretly distrusts all human language. Indoors you confront words - outdoors you confront things. Edwin prefers roaming over a referent to sweating over a signifier.

This linguistic 'anti-structuralist' reading of The Minstrel becomes more plausible when Beattie's intimacy with Reid is considered. He had not only read Reid's book, he had many times heard Reid explain it. Reid expounded two distinct dimensions of communication - natural and 'artificial' language the former being divinely implanted, a meta-grammar of communicative competence. Without this sacred gift, the facility of language would not and could not be ubiquitous. In an astonishing digression, Reid goes further, and speaks of linguistic sophistication as a diminution, a falling off of the creative potential of humanity: 'Abolish the use of articulate sounds and writing among mankind for a century, and every man would be a painter, an actor, and an orator' (Reid, Inquiry, p. 109). The idea that everyone would become a creative spirit if deprived of the power of speech is, I would argue, a profoundly romantic notion. Proto-romantic auto-luxuriance enables silence to become a precondition of expressiveness. Silent solitary Edwin, eyes open to the mountains and the heavens has access to an expansively fruitful dimension of experience that the world inhibits only with great loss. The less he talks, the more he speaks. This resonant but mute figure, familiar to us through the Prelude, will one day attract the scrutiny of Lacan and Kristeva. The reconstruction of a presymbolic semiotic chora is a suggestive response to Hume, and Beattie's one genuine, albeit rhetorical, contribution to philosophy: 'children . . . do generally, if not always, speak as they think, and ... it has passed into a proverb, that children and fools tell truth' (Beattie, Essay on Truth, p. 136). 
Beattie's most astonishing depiction of childlike wisdom is that of his own elder son, James Hay Beattie, whose learning, piety and creative potential make him read like an amalgam of Edwin, Chatterton and the young Wordsworth - a marvellous boy with a vengeance. This paragon of innocence and promise died in 1790, aged twenty-two, and his father soon contrived the publication of his literary remains, together with an account of his short life and long list of qualifications (he had been made Assistant Professor of Moral Philosophy at Marischal at the age of eighteen). No matter how much learning the boy absorbed, he still preserved his naive simplicity and a miraculous resistance to adult corruptions: 'He could instantly, and almost intuitively, discern what in human conduct was right or wrong, ... not only in matters of morality and science but in the general intercourse of the world. ... I never went wrong by following his advice.' ${ }^{21}$ Like Edwin 'he was not frequently seen in the street; a laudable regard to health, and a passionate love of rural scenery, leading him to daily excursions in the fields' (James Hay Beattie, p. 66). Like his father, James Hay worshipped Gray's poetry: his fragmentary magnum opus, A Poem on the Excellence of Christianity, opens with an invocation of Deity consisting entirely of a roll call of great British poets: Shakespeare, Pope, Gray and Milton. The creation of a bard is an evidence of Divinity presumably more potent than any formal argument from design.

Even Divinity cannot grow a bard in a greenhouse. James Beattie's investigation of the bardic psyche appears even more quasi-religious when his poetic and the philosophical endeavours are considered together. Beattie, with Christ-like condescension, takes on the distressing burden of reading and thinking about Hume. He descends into Hell on our behalf, undergoes pain, and is resurrected in glory, firstly at the Sheldonian Theatre (9 July 1773) (where the awarding of his honorary doctorate provoked 'special applause'), and latterly in Reynold's painting. He ventures into the netherworld of the artificial in order to reclaim and vindicate the natural and the transcendental.

It is clear that David Hume unwittingly provided the context for Beattie's romantic exploration of his own formative state of precognition, since The Minstrel cannot be dislocated from the intellectual and emotional demands of forging the Essay on Truth. Writing to the Dowager Lady Forbes, 12 October 1772, Beattie admits the autobiographical elements in The Minstrel. Dramatic scenery 'had charms in my eyes, even when I was a schoolboy; and at a time when I was so far from being able to express, that I did not understand my own feelings' (Letters, 1, 98). As a schoolboy he had one day climbed a lofty eminence to achieve a first sight of the ocean that he would recall intensely for the rest of his life: 
And oft the craggy cliff he loved to climb, When all in mist the world below was lost.

What dreadful pleasure! there to stand sublime, Like shipwreck'd mariner on desert coast, And view th'enormous waste of vapour, tost In billows, lengthening to th'horizon round, Now scoop'd in gulfs, with mountains now emboss'd! And hear the voice of mirth and song rebound, Flocks, herds, and waterfalls, along the hoar profound!

(Book I, XXI)

Sublimity is here drawn as a vaporous confusion of big, raw elements: the stanza does not try to interpret the experience in moral (let alone theological) terms. Beattie's dreadful pleasure resembles that of J. M. W. Turner, strapped to the mast, the better to paint 'Steamer in a Snowstorm' (1842).

This sort of sublime abstraction had an excitement for Beattie that nonetheless failed to disrupt his own religious and political orthodoxy. Empiricism reassures him while abstraction humbles yet excites. Beattie offers a mixture of knowledge and ignorance; he combines childlike faith in the instructive reality of Nature with an honest inability to dissect or delimit the totality and immensity of Nature's impact. It is true that the romantic tendencies within his poetry and prose were originally intended primarily as bold tropes designed to reinforce a set of very familiar messages, and that he identified the Author of the Sublime absolutely with the God of the Scriptures. However, the same techniques of spiritual consolation and selfreinforcement offered by Beattie would one day be appropriated by that bold atheist, Percy Shelley:

Whosoever is free from the contamination of luxury and licence may go forth into the fields and to the woods inhaling joyous renovation from the breath of Spring, or catching from the odours and sounds of autumn, some diviner mood of sweetest sadness which improves the heart. Whosoever is no deceiver or destroyer of his fellow men, no liar, no flatterer, no murderer may walk among his species, deriving from the communion with all which they contain of beautiful or of majestic, some intercourse with the Universal God. Whoever had maintained with his own heart the strictest correspondence of confidence, who dares to examine and to estimate every imagination which suggests itself to his mind, who is that which he designs to become, and only aspires to that which the divinity of his own nature shall consider and approve ... he, has already seen God. ${ }^{22}$ 
Shelley builds this paragraph in order to effect a continuous progression from traditional Christian pastoral through 'ecumenical' deism towards the atheism of romantic auto-sublimity. The seamlessness of this progress is (from a Christian perspective) especially frightening. It is a brief but irrevocable step from seeing evidence of Divinity within the constitution of every awakened sensibility to seeing Divinity as awakened sensibility. As ever, Beattie appears to have been unaware of the stakes, unaware of the full consequences of prosecuting his intellectual and imaginative methods. The shy, sickly polymath from Aberdeen, while making his appeal to intuitive childlike impulses, helped unleash forces he could not hope to delimit or control. $\mathbb{R}$

Department of English Saint Patrick's College, Maynooth

1. James Boswell, Life of Johnson, ed. by R. W. Chapman, 3rd edn, corr. by J. D. Fleeman (Oxford: Oxford University Press, 1970), p. 550.

2. Letters and Prose Writings of William Cowper, ed. by James King and Charles Ryskamp, 5 vols (Oxford: Clarendon Press, 1979-86), II, p. 231.

3. See John Lucas, 'Revising Clare', published in Romantic Revisions, ed. by Robert Brinkley and Keith Hanley (Cambridge: Cambridge University Press, 1992), p. 345; T. J. Diffey, 'The Roots of the Imagination: the philosophical context', published in The Romantics: the Context of English Literature, ed. by Stephen Prickett (London: Methuen, 1981), pp. 164-201; Marilyn Gaull, English Romanticism: The Human Context (New York \& London: Norton, 1988), p. 262,

4. Everard H. King, James Beattie's 'The Minstrel' and the Origins of Romantic Autobiography (Lewiston, New York; Queenston, Ontario; Lampeter: Mellen Press, 1992), pp. 17-18.

5. The Letters of William and Dorothy Wordsworth, ed. by Ernest De Selincourt, 2nd edn, The Early Years, 1787-1805, rev. by C.L.Shaver (Oxford: Clarendon Press, 1967), pp. 100-1, hereafter cited as Wordsworth Letters in the text.

6. The Minstrel, or The Progress of Genius, in two books: with some other poems, 6th edn (London: Printed for E. \& C. Dilly, 1779), p. 5. All subsequent references are taken from this edition.

7. James Beattie, An Essay on the Nature and Immutability of Truth; In Opposition to Sophistry and Scepticism (Edinburgh: Printed for A. Kincaid and J. Bell, 1770) p. 292. All subsequent references are taken from this edition, cited Beattie, Essay on Truth.

8. Quoted in Margaret Forbes, Beattie and his Friends (London: Constable, 1904), p. 44.

9. The Letters of James Beattie, Chronologically Arranged from Sir William Forbes's Collection, 2 vols (London: John Sharpe, 1819-21), I, p. 25, hereafter cited as Letters.

10. James Beattie, Elements of Moral Science, 2 vols (Edinburgh: Printed for W. Creech, 1790-3), II, p. 589,

11. James Beattie, Essays, On Poetry and Music as they affect the Mind, On Laughter and Ludicrous Composition, On the Utility of Classical Learning (Edinburgh: Printed for W. Creech, 1776), p. 540, hereafter Beattie, Essays. 
12. Joseph Priestley, An Examination of Dr. Reid's Inquiry into the Human Mind on the Principles of Common Sense, Dr. Beattie's Essay on the Nature and Immutability of Truth, and Dr. Oswald's Appeal to Common Sense in Behalf of Religion (London: Printed for J. Johnson, 1774), pp. 202-3.

13. Thomas Blackwell, An Enquiry into the Life and Writings of Homer (London, 1735; facsimile reprint, Menston: Scolar Press, 1972), pp. 55-6, hereafter Blackwell.

14. William Duff, Essay on Original Genius, 2nd edn (London: Printed for Edward and Charles Dilly, 1767), p. 288.

15. The Poetical Works of James Beattie, (London: Aldine, 1831), p. 148.

16. Beattie described Rousseau as 'one of the greatest philosophers in the world, if his genius had not been perverted by the faction of the times and by the love of paradox'. Letter to Sir William Forbes, 16 November 1772, Letters, I, p. 116.)

17. Thomas Reid, An Inquiry into the Human Mind, on the Principles of Common Sense (Edinburgh: Printed for A. Kincaid and J. Bell, 1764), pp. 30-1.

18. Ernest Campbell Mossner, 'Beattie's "The Castle of Scepticism": An unpublished Allegory against Hume, Voltaire and Hobbes', Studies in English, vol. XXVII (Austin, Texas: University of Texas Press, 1948), pp. 108-45.

19. James Beattie, Evidences of the Christian Religion; briefly and plainly stated, 2 vols (Edinburgh: Printed for W. Creech, 1786)

20. Boswell: the Applause of the Jury, ed. by Irma S. Lustig and Frederick A. Pottle (New York: McGraw Hill; London: Heinemann, 1980), p. 31.

21. James Hay Beattie, Essays and Fragments in prose and verse. To which is prefixed an account of the author's life and character (Edinburgh: Printed for J. Moir, 1794), p. 52, hereafter cited as James Hay Beattie.

22. Percy Bysshe Shelley, 'On Christianity' (1817), published in The Prose Works of Percy Bysshe Shelley, ed. by E. B. Murray (Oxford: Clarendon Press, 1993-), Vol I, p. 251. 